regard to the arrangements for the Austrian Expedition to the Congo ; a sketch of the results of Danish explorations in Greenland by A. Rink ; the conclusion of Dr. Breitenstein's paper on Borneo, and the recent letters of Colonel Prjevalsky. Dr. Breitenstein's account of Borneo is of great interest. He points out that in this great island may be studied in succession almost every stage of human development from the lowest to the highest. It is not sixty miles, for example, from Pengaron, where European machinery is employed in the coal mines, to Punun or Olo Ott, where the people are almost quite naked, and where their only protection from the weather is a grass hut here and there. It is hardly a hundred miles between Banjermassin, where Eurpean war-vessels and Krupp guns keep the Dyaks in check, and the kampong of the Prince of Murong which is protected by a thin palisade, from the top of which the heads of those captured in raids look down on the traveller. In this narrow district we have a kaleidoscopic picture of all the steps of human civilization.

AT the last meeting of the Geographical Society of Paris, M. du Caillaud read a note on the fortress of Camlo in Annam, to which the attack on the French at Hue has just given some importance ; M. de Lesseps referred to soundings recently made at Gabes with a view to establishing a fort there; $M$. Rouire, who has recently returned from a scientific mission to Tunis, recounted his explorations in the regions between Kairwan, Susa, Hammanet, and Lake Felbiah. M. Delaplanch also read an account of a journey which he made through the centre of Persia, from Resch on the Caspian to Teheran.

Dr. P. L. SClater suggests "Torresia" as an appropriate name for British New Guinea.

In the Bollettrno of the Italian Geographical Society for July, Sig. Buonfanti publishes a reply to the doubts of Herr G. A. Krause on his journey from Tripoli across the Sahara and Western Sudan to the coast of Guinea. The writer, whose letter is dated May 6, on board the Corisco at Banana, states that documentary proofs of the trip cannot be given till his arrival in Brussels, where the papers lie under lock and key in charge of Prof. du Fief. They include, he says, correspondence already forwarded to two American journals from Tripoli, Murzuk, \&c., besides translations of safe-conducts and firman received from the Sultans of Bornu and Socoto, and of a letter from the Sheikh [sic] of Timbuktu, the originals of which will be forthcoming. There are also accounts, invoices, \&c., of Maltese dealers, certificates of sea-captains, certificates of missionaries, and so forth. He explains that Herr Krause heard nothing of his movements at Lagos, because he reached the coast not at that place, but at Portonuovo, some 45 miles further west. For the same reason nothing was known of him in the Yoruba country, which lies 200 miles to the east of Dagomba, Bagouza, Dahomeh, and the other districts through which he travelled.

THE Vienna Geographical Society has received good news of Dr. Oscar Lenz's African exploring expedition, which, on July 17, had reached Monrovia, the capital of Liberia. The next news will be from the Cameroons.

THE death is announced from Sydney of Thomas Boyd, the first white man to cross the Murray river, and the last surviving member of Hume and Hovell's exploring party. He was eightyeight years of age, and had lived in great poverty for some years prior to his death.

\section{MEASUREMENT OF EVAPORATION}

I SEND a brief sketch of an instrument which I have just made for the measuring of evaporation from a water surface. The figures and letters refer to the accompanying drawings:-

Fig. 1, A. - Tank-mine, 20 in. $X$ to in., standing in a large tank 60 in. $\times 40$ in. The sides are double, a space one-tenth of an inch being between the walls and opening all around inner wall (a) with an outflow-pipe (Figs. $3,4, \mathrm{G}$ ) let into bottom. Tank filled as Fig. 4, and refilled every three or four hours, the amount poured in being carefully measured.

Fig. I, A, B, C.-Complete instrument. A, evaporating-tank ; $\mathrm{B}$, reservoir filled with water to $(n) ;(h)$ a graduated glass coil, by which water pouring out through tap $(l)$ is registered. Pressure upon tap regulated by (i) a tube and funnel buoyed up by $(k)$. Water flows from $\mathrm{B}$ to $\mathrm{A}$ through a perforated, semicircular chamber $(e)$, which makes water spread over the entire surface of tank. Overplus flows over at $(f)$ down $\left(c, d^{\prime}\right)$ into reservoir C, similar to $\mathrm{B}$ in fittings. Then loss from $\mathrm{B}-$ gain in $\mathrm{C}=$ the evaporation from $\mathrm{A}$. This arrangement intended chiefly for experimentation upon running water, removes the necessity for refilling the tank, although good results can be attained even then.

Fig. 2.-Tank from above. (a) space between walls; (b)

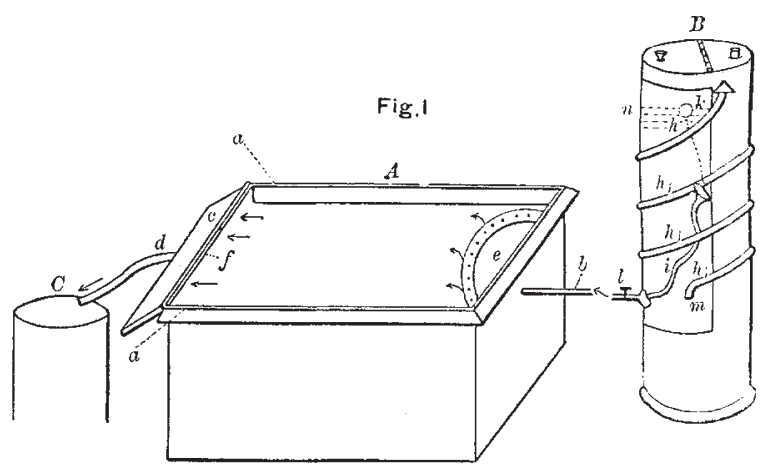

inflow-pipe from $\mathrm{B} ;(e)$ perforated chamber or rose ; $(d)$ outflowpipe.

Fig. 3.-End of tank; letters as before. The outer wall in part cut away to show chamber $(a)$ with emptying-pipe $(g)$.

Fig. 4.-Transverse section : $(o o)$, walls ; $(a)$, space ; $g$, pipe ; $p$, strengtheners. Height of water also represented.

The following points are worthy of notice :-

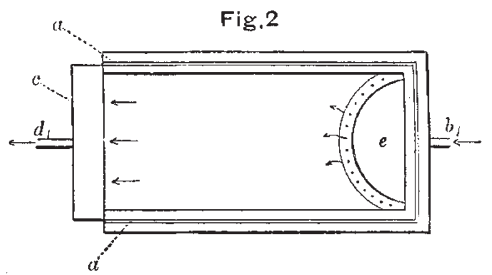

(I) The level of the water can be kept constant by regulating the flow from the tap $l$ (Fig. I, B).

(2) Error arising from splashing out of water, when heavy wind blowing, removed, the displaced water flows down (as Fig. 2), and through pipe $g$ (Fig. 3 ), and is collected in a small measured vessel.

(3) Error arising from rainfall similarly corrected; rain falling

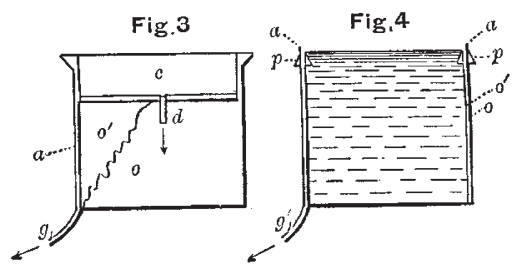

into $\operatorname{tank} \mathrm{A}$, for greater part flows off at $f$, and is collected in $\mathrm{C}$; when very heavy, flows also into $\alpha$, and is collected is mentioned above. Then, the amount of rainfall being known from the rain-gauge, the following simple process gives the evaporation : $-x=$ rainfall in cubic cents. ; $y=$ water in reservoirs; $x-y=$ evaporation in cubic cents. GEORGE HASLAM

Trinity College, Toronto

\section{UNIVERSITY AND EDUCATIONAL INTELLIGENCE}

THE following candidates have been successful in the competition for the Whitworth Scholarships, 1885 , in the Science and Art Department, South Kensington:-Thomas Clarkson, age 20, engineer, Manchester, 200l.; Hugh O. Bennie, 2o, engineer, Glasgow, 150l. ; Robert H. Unsworth, 20, engineer, Pendleton, near Manchester, I50l.; Harold M. Martin, 2I, engineer, 
Gateshcad, I5ol.; William T. Calderwood, 25, mechanical draughtsman, Glasgow, and John Richards, 22, blacksmith, Cardiff, equal, $150 l$. each ; tirnest R. Dolby, 23, engineer, Leeds, 150l. ; James Rorison, 2I, engine fitter, Paisley, 150l.; Arthur J. Moulton, 20, engineer apprentice, Preston, 150l.; William McNeill, 22, mechanic, Birmingham, rool. ; Gcorge W. Moreton, 24, fitter, Crewe, Iool. ; Stephen E. Mallinson, 24, assistant analyst, London, rool. ; Henry C. Jenkins, 23, engineer and millwright, London, Iool.; Robert Smith, 24, engineer, Glasgow, 100l.; Thomas W. Nash, 2I, engineer, London, Iool.; Henry F. W. Burstall, I9, engineer apprentice, London, 100l.; Arthur J. Stopher, 22, mechanical engineer, Nottingham, Iool. ; Sidney II. Wells, I9, marine engincer apprentice, London, rool. ; George Milnes, 24, fitter, Charlton, Kent, rool. ; Henry Begbey, 22, engineer, Old Chariton, Kent, 1ool. : John Goodman, 23, engincer, Brighton, 100l. ; Mark H. Crummie, 2I, mechanical engineer, Hull, Iool. ; Oliver Marsh, 22, fitter and turner, Crewe, rool. ; Thomas Galbraith, 23, pattern maker, Manchester, Iool.; Joseph H. Bowles, 23, engine fitter, Stratford, rool.

\section{SCIENTIFIC SERIALS}

American Fournal of Science, June.-Notes on American earthquakes, with a summary of the seismic disturbances recorded in North and South America and adjacent waters during the year I 884 , by C. G. Rockwood, jun.-Taconic rocks and stratigraphy (continued) : V. metamorphism and mineral constitution in the Taconic region, gradational from west to east and from north to south, by James 1 ). Dana. - Notes on the possible age of some of the Mesozoic rocks of the Queen Charlotte Islands and British Columbia, by J. F. Whiteaves.-Crystallised Tiemannite and metacinnabarite, by Samuel L. Penfield. To the paper is appended a note by Prof. J. E. Clayton on the occurrence of 'liemannite in a mine 200 miles south of Salt I ake City.-On the gahnite occurring in the Davis Mines of Rowe, Massachusetts, - The genealogy and age of the species in the southem Old Tertiaries, by Dr. Otto Meyer. - On some specimens of meteoric iron from Trinity County, California, by Charles Upham Shepard. The analysis yiclded : iron, 88.810; nickel, 7.278; cobalt, O'I 72 ; phosphorus, O'I 20. - The Potsdam group east of the Blue Ridge at Balcony Falls, Virginia, by II. D. Campbell.--GeJlogy of the sea-bottom in the approaches to New York Bay, by A. Lindenkoh1.-Additional notes on the Kettle-Holes of the Wood's Holl region, Massachusetts, by 13. F. Koons.-Cause of the apparently perfect cleavage in American sphene (titanite), by G. H. Williams.

American Fournal of Science, July.-Contributions to meteorology. Twenty-first paper : direction and velocity of movement of areas of low pressure, by Prof. Elias Loomis. The paper is accompanied by numerous tables showing the average direction of storm tracts, the comparative tracts of storm and atmospheric currents over the Atlantic and United States, the progress of storm centres in Europe. - Note on some Palæozoic Pteropods, by Charles $\mathrm{D}$. Walcott. With some hesitation the writer includes in the Pteropod group such organisms as Conularia, Hyolithes, Coleolus, Salterella, Pterotheca, as well as Matthevia, which is here chiefly dealt with. This peculiar shell, which he so names in honour of Mr. G. F. Matthew, is, however, so distinct from all described forms of Pteropoda that a new family Matthevidæ, is proposed to receive the one genus now known. -A determination of the B.A. unit in terms of the mechanical equivalent of heat, by Lawrence B. Fletcher. The experimental work here described was completed in I88I, and forms the subcct of a thesis submitted to the Johns Hopkins University in that year. In the present paper a more accurate method of calculating the currents from the deflection-curves is used, and some of the other calculations have been revised. But in other respects the results of the two papers are substantially the same. The experiment consists of simultaneous thermal and electrical measurements of the energy expended by a current in a coil of wire immersed in a calorimeter. The result depends upon the values of the mechanical equivalent and the unit of resistance, and gives a determination of either in terms of an assumed value of the other.-Cause of irregularities in the action of galvanic batteries, by Hammond V. Hayes and John Trowbridge. Here is investigated the phenomenon known as "endosmose," that is, the action by which the electric current carries whatever comes in its way from the positive to the negative electrode. -
On the sensitiveness of the eye to colours of a low degree of saturation, by Dr. Edward L. Nichols. - A study of thermometers intendcd to measure temperatures from $100^{\circ}$ to $300^{\circ} \mathrm{C}$., by O. 'T. Sherman.-Notice of a new Limuloid clustacean from the Devonian formations of Erie County, Pennsylvania, by Henry Shaler Williams. This specimen, provisionally identified with Prestwichia, would appear to throw back the range of that group to an earlier period than hitherto reported. The earliest previously-discovered Prestwichia occurs in the Carboniferous formations. - Gerhardtite and artificial basic cupric nitrates, by H. I. Wells and S. L. Penfield. The mineral bere described under the name of Gerhardtite was first identified as a new species by Prof. Geo. J. Brush, who found it among a lot of copper minerals from the United Verde Copper Mines, Jerome, Arizona. Its specific gravity is 3.426 ; hardness, 2; colour, dark green; streak, light green; transparent ; crystals, orthorhombic. - On the occurrence of fayalite in the lithophyses of obsidian and rhyolite in the Yellowstone National Park, by Joseph P. Iddings. - The gencalogy and age of the species in the Southern Old Tertiary. Part 2. The age of the Vicksburg and Jackson Beds, by Dr. Otto Meyer. - On the probable occurrence of the great Welsh Paradoxides ( $P$, davidis) in America, by Geo. F. Matthew. This largest and most remarkable species of Paradoxides occurring in the primordial fauna of Europe was first discovered about twenty years ago by Dr. Henry Hicks near St. David's, Wales, and subscquently (1869) in Sweden. But its presence has only recently been suspected in America, where specimens of large species appear to occur both in the Cambrian slate at Saint John, New Brunswick, and in a hard silico-calcareous shale at HIighland's Cove, Trinity Bay, Newfoundland.

Bulletin of the Philosophical Society of Washington, vol. vii. - Besides the usual reports of the officers of the Society, this volume contains a learned address by the President (Mr. James C. Welling) on the atomic philosophy, physical and metaphysical ; abstracts, among other, of papers by Mr. W. II. Dale, on recent advances in our knowledge of limpets; by $\mathrm{Mr}$. Kussell, on the existing glaciers of the IIigh Sierra of California ; by Prof. Kerr, on the mica mines of North Carolina; by Mr. Riley, on recent advances in economic entomology, in which the part which insects play in the economy of nature, and particularly their influence in American agriculture, were discussed. Mr. Burnett explained why the eyes of animals shine in the dark. It is not due, he says, to phosphorescence, as has been commonly supposed, but to light reflected from the bottom of the eye, which light is diffused on account of the hypermetropic condition that is the rule in the lower animals. Mr. Johnson writes on some eccentricities of ocean currents, compiled from the records of the Lighthouse Board; Mr. Clarke on the periodic law of chemical elements; Mr. Ifazen, on the recent sun-glows; Mr. Russell, on deposits of volcanic dust in the grcat basin; Mr. Gilbert, on the diversion of water-courses by the rotation of the earth; Mr. Doolittle, on music and the chemical elements; Mr. Bates, on the physical basis of phenomena (which is printed in full). Mr. Gilbert presented a plan for the subject, bibliography of North American geological literature; Mr. Matthews, in a paper bearing the title of natural naturalists, combated the notion that savages are versed only in the knowledge of animals and plants which contribute to their wants. The writer found that Indians have a comprehensive knowledge of animals and plants; as a class the Indians "are incomparably superior to the average white man, or to the white man who has not made zoology or botany a subject of study." The Indian also is as good a generaliser and classifier as his Caucasian brother. Several speakers who followed agreed in this conclusion.-Mr. Dutton has a paper on the volcanoes and lava fields of New Mexico.The following are among the principal papers in the Mathematical Section : Mr. Gilbert, on the problem of the Knight's tour; Mr. Farquhar, on empirical formulæ for the diminution of amplitude of a freely oscillating pendulum; Mr. Hall, on the formulæ for computing the position of a satellite (which is printed in full); Mr. Kummel, on the quadric transformation of elliptic integral;, combined with the algorithm of the arith. metico-geonetric mean.

Bulletin de l'Acadénie Royale de Belgique, May.-M. Ch. Fievez, on the influence of magnetism on the characters of the spectral rays. The increase of the luminous intensity of the spark and its spectrum is attributed to the action of magnetism 